\title{
RADIOCARBON DATING SITES OF ITAPARICA DAM, SÃO FRANCISCO RIVER VALLEY, BRAZIL
}

\author{
L R P de Andrade Lima \\ Department of Materials Science and Technology, Federal University of Bahia, C.P. 6974, Salvador, Bahia, Brazil, \\ 41810-971. Email: lelo@ufba.br.
}

\begin{abstract}
This paper reports radiocarbon dates of samples from archaeological sites in the Itaparica Dam region of the São Francisco River (Brazil). This region is important due to the evidence of its use by several prehistoric groups of huntergatherers. In the 1980s, a Brazilian state hydroelectric company (CHESF) engaged the federal universities of Bahia and Pernambuco to perform an archaeological rescue excavation at the Itaparica Dam reservoir area. This excavation allowed the collection of a large number of ceramics and lithic artifacts as well as fireplace charcoal. In this study, fireplace charcoal samples from the Bahia State riverside of the Itaparica Dam were selected and used for dating purposes. The ${ }^{14} \mathrm{C}$ ages were between 3840 and $210 \mathrm{BP}$, and the values of $\delta^{13} \mathrm{C}$ range from -22.93 to $-24.81 \%$. The ${ }^{14} \mathrm{C}$ dates, in addition to the archaeological findings, indicate that the presence of humans in the region was contemporary with the intermediate levels of older sites found in the adjacent area, and also indicate different settlement periods.
\end{abstract}

\section{INTRODUCTION}

The archaeological sites near the São Francisco River, NE Brazil, are rich and have been described by several authors (Calderón 1967, 1969, 1972, 1983; Prous 1986; Dillehay et al. 1992; Martin 1999). For example, Gruta do Padre Cave, located in the Itaparica region (Pernambuco State, NE Brazil), provided abundant lithic material such as thick scrapers and planes made of pebbles collected at the nearby São Francisco River. This material is representative of the Itaparica tradition, which is characterized by thick unifacial instruments without bifacial projectile points (Schmitz 1987; Prous 1986; Prous and Fogaça 1999).

Some radiocarbon dates are available for the São Francisco River region: 1700 BP (Beta-21519) at Letreiro do Sobrado (Pernambuco State); 7500 BP (SI-644) at Gruta do Padre (Pernambuco State); 9000 BP (Beta-84439 and Gif-3208) at Lapa Vermelha in the Lagoa Santa region (Minas Gerais State, SE Brazil); 9000 BP (SI-6296 and SI-6298) at Furna do Estrago (Pernambuco State); and $\sim 14,000$ BP at São Raimundo Nonato region (Piauí State, NE Brazil) (Calderón 1969, 1983; Prous 1986; Martin 1989; Peyre 1993; Prous and Fogaça 1999; Santos et al. 2003; Neves et al. 2004). While the anthropogenic origin of the charcoal from several sites is controversial and the thermoluminescence dates for rockwall painting are also under intense debate, several older than expected ${ }^{14} \mathrm{C}$ dates were found in sites of the Capivara National park region (Piauí State) (Prous and Fogaça 1999; Santos et al. 2003; Watanabe et al. 2003; Rowe and Steelman 2003).

A Brazilian state hydroelectric company (CHESF) started the construction of a dam in the Itaparica Falls (de Souza 1945) in 1974, and in 1988, $834 \mathrm{~km}^{2}$ of land was flooded by the $150-\mathrm{km}$-long reservoir (Nazario et al. 1979; Portella 1992). The Itaparica Dam (recently renamed Luiz Gonzaga Dam) is located at $8^{\circ} 00^{\prime}$ to $9^{\circ} 30^{\prime} \mathrm{S}, 38^{\circ} 00^{\prime}$ to $39^{\circ} 30^{\prime} \mathrm{W}$, near the border of the Bahia and Pernambuco states, $520 \mathrm{~km}$ from the city of Salvador, above the Sobradinho Dam, in the lower-middle section of the São Francisco River (see Figure 1) (de Souza 1945; Nazario et al. 1979; Portella 1992).

The CHESF engaged the Federal University of Bahia (UFBA) to develop an archaeological rescue excavation at the São Francisco River at the Itaparica Dam reservoir area, on the Bahia State riverside, which includes the cities of Abaré, Chorrochó, Rodelas, and Glória. This excavation allowed for the collection of a large number of ceramics and lithic artifacts $(>11,000)$ in addition to fireplace charcoal, natural fibers, food remains, and other materials. Identification of the fireplaces was done by the archaeologists working on this project and took into account the geometric form of the place 


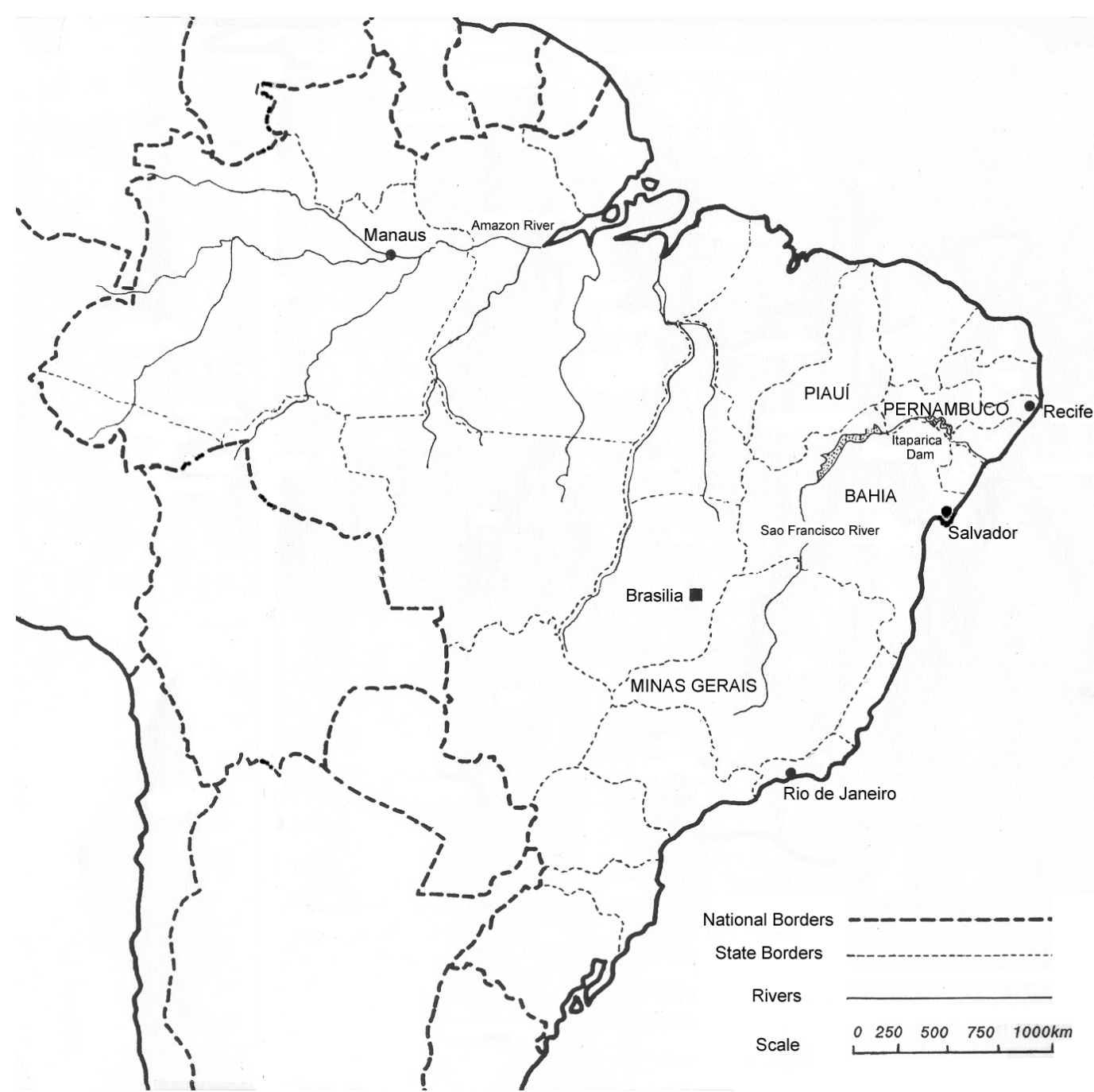

Figure 1 Map of the Itaparica Dam location in the São Francisco River valley, NE Brazil, $520 \mathrm{~km}$ from the city of Salvador (Bahia State) and $450 \mathrm{~km}$ west of the city of Recife (Pernambuco State) (adapted from Portella 1992).

where the charcoal samples were found and the anthropogenic artifacts found in the surrounding area. Some of the fireplace charcoal samples were selected and used for dating the sites presented here. Facilities at the Laboratory of Nuclear Geophysics at the Federal University of Bahia, which includes a combustion and purification line, a decay counting system, and mass spectrometers Nuclide 3-60-RMS and Finnigan Deltaplus, were used in the present study. This facility has been widely used since the 1970s for dating groundwater, carbonates, organic matter, and other materials of interest to experts in geophysics, especially for studies in geochronology, paleoclimatology, and recently for oil pollution characterization. Despite the fact that archaeological dating is not the main focus of this facility, in conjunction with the archaeologists that worked in the rescue project, a limited but very relevant number of samples to date have been determined.

Some results of the studies that followed the archaeological rescue excavation in the Itaparica Dam area were reported to the CHESF and to the Brazilian scientific community, but several results 
remain unknown to the international community (Almeida and Galvão 1986; da Silva 1987; Etchevarne 1991). Therefore, the main objective of the present work is to provide new ${ }^{14} \mathrm{C}$ dates that can be used to enhance the understanding of the prehistory of this important Brazilian archaeological region. This work is significant because most of the ${ }^{14} \mathrm{C}$ dating results for the Itaparica Dam area are unpublished.

\section{THE ITAPARICA DAM SITES}

The Itaparica Dam region presents tabular terrains, dunes, and eroded scarps that are also modeled by wind and water, i.e. eolian and fluvial accumulations. The area is characterized by semiarid warm weather with an average temperature of $\sim 26-27^{\circ} \mathrm{C}$ and irregular rainfall accumulation from October to April of $<750 \mathrm{~mm} / \mathrm{yr}$. The altitude varies between 300 and $800 \mathrm{~m}$, and the vegetation is characterized by steppe plants with a few palms (Almeida and Galvão 1986; da Silva 1987; Etchevarne 1991).

The Federal University of Bahia performed the archaeological rescue excavation at the Itaparica Dam reservoir region, located at the Bahia State riverside, in 2 periods, June 1984 and May 1987. Figure 2 schematically shows the map of the studied region along with the reservoir inundation level of the dam (dotted line); the location of some archaeological sites; and current cities and towns, which include Glória, Rodelas, Chorrochó in Bahia State, and Belém do São Francisco, Itacuruba, Floresta, and Petrolândia in Pernambuco State.

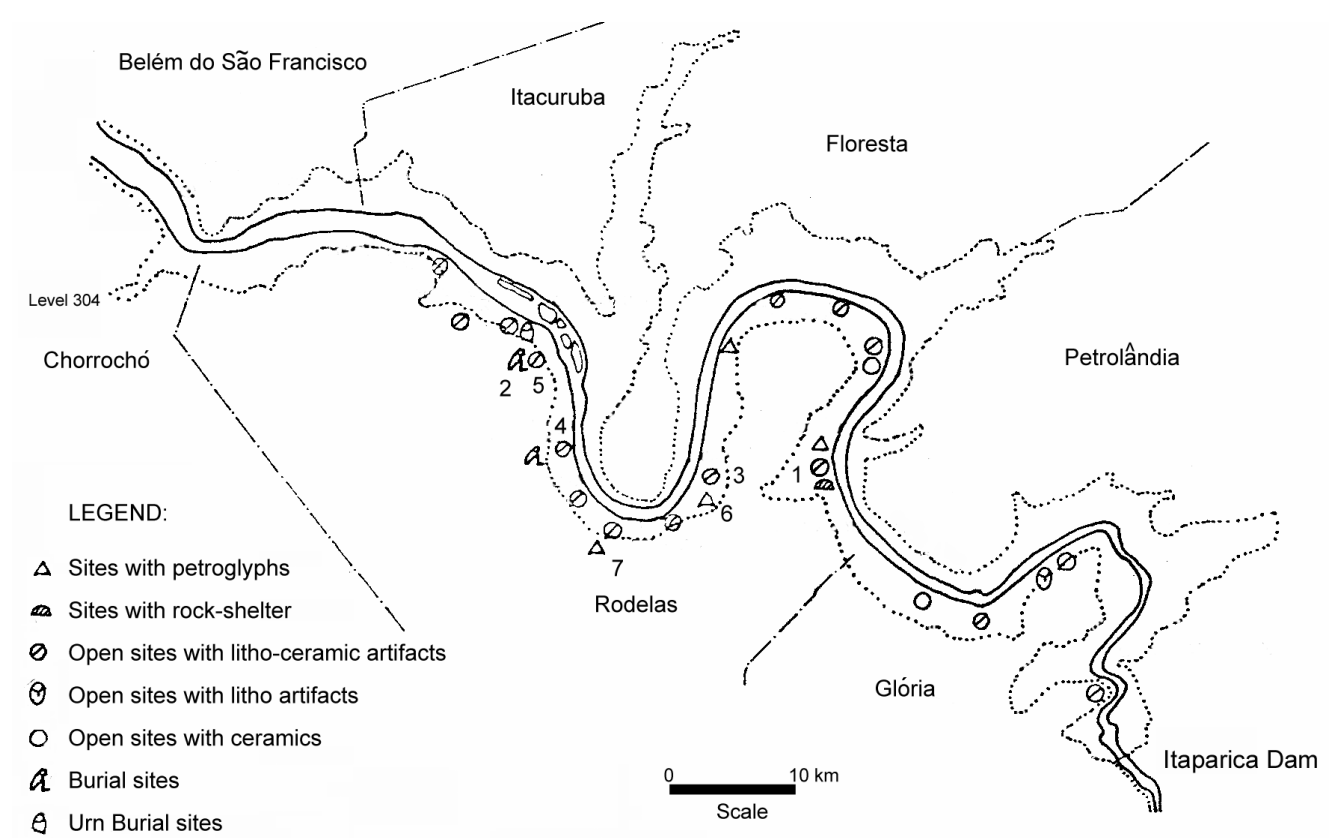

Figure 2 Map showing the location of archaeological sites on the Bahia State side of the Itaparica Dam: 1: Itacoatiara I; 2:Paraíso; 3: Guga; 4: Aldeia do Vinho; 5: Tapera Velha-Casa Oeste; 6: Bebedouro das Pedras; 7: Pedra da Moeda. The dotted line represents the inundation level $(304 \mathrm{~m})$ of the dam, and the dot-dashed line represents the border between the cities (adapted from da Silva [1987]).

In the tabular terrains near the river, several types of boulders were found, including silex, chalcedony, and other varieties of quartz, which were used as raw material for the production of lithic arti- 
facts (Almeida and Galvão 1986; da Silva 1987; Etchevarne 1991). The archaeological sites dated in this study are described below.

\section{a) Itacoatiara I}

This site $\left(8^{\circ} 58^{\prime} \mathrm{S}, 30^{\circ} 30^{\prime} 44^{\prime \prime} \mathrm{W}\right)$ is located between the cities of Rodelas and Gloria, near the base of the Curral Mountains and Itacoatiara Creek (see Figure 2). This site is characterized by open panels in the mountains with petrogliphs. This is a fertile site, where 3064 lithic artifacts, 145 ceramic fragments, 4 stamps with petrogliphs, 2 arenitic blocks with petrogliphs, food and vegetable remains, bones, and fireplace charcoal were found in previous excavations (Almeida and Galvão 1986; Etchevarne 1991).

Figure 3 shows excavation photos of Itacoatiara I. Note in the figure the panels, arenitic stone blocks, and stamps with petrogliphs that characterize this site (Almeida and Galvão 1986; Etchevarne 1991).
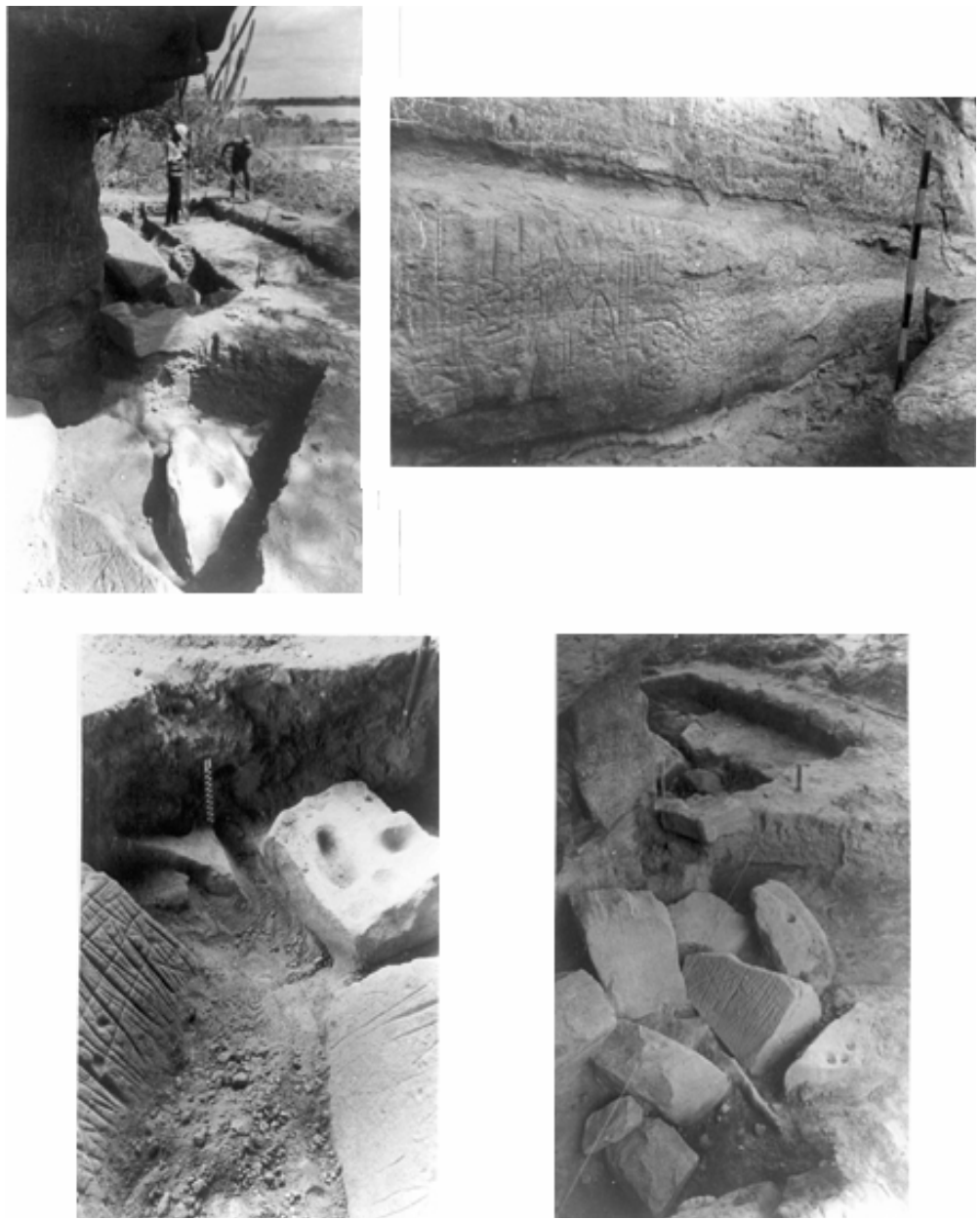

Figure 3 Photos of the archaeological site Itacoatiara I, located in Rodelas (see Figure 2), showing the panels, arenitic stone blocks, and stamps with characteristic petrogliphs (Almeida and Galvão 1986). 
Figure 4 shows photos of 2 open sites with petrogliphs located close to the Itacoatiara I site. The sites Bebedouro das Pedras and Pedra da Moeda are not dated in the present study, but help to illustrate the petrogliphs that characterize the archaeological sites of this area (Almeida and Galvão 1986; Etchevarne 1991).
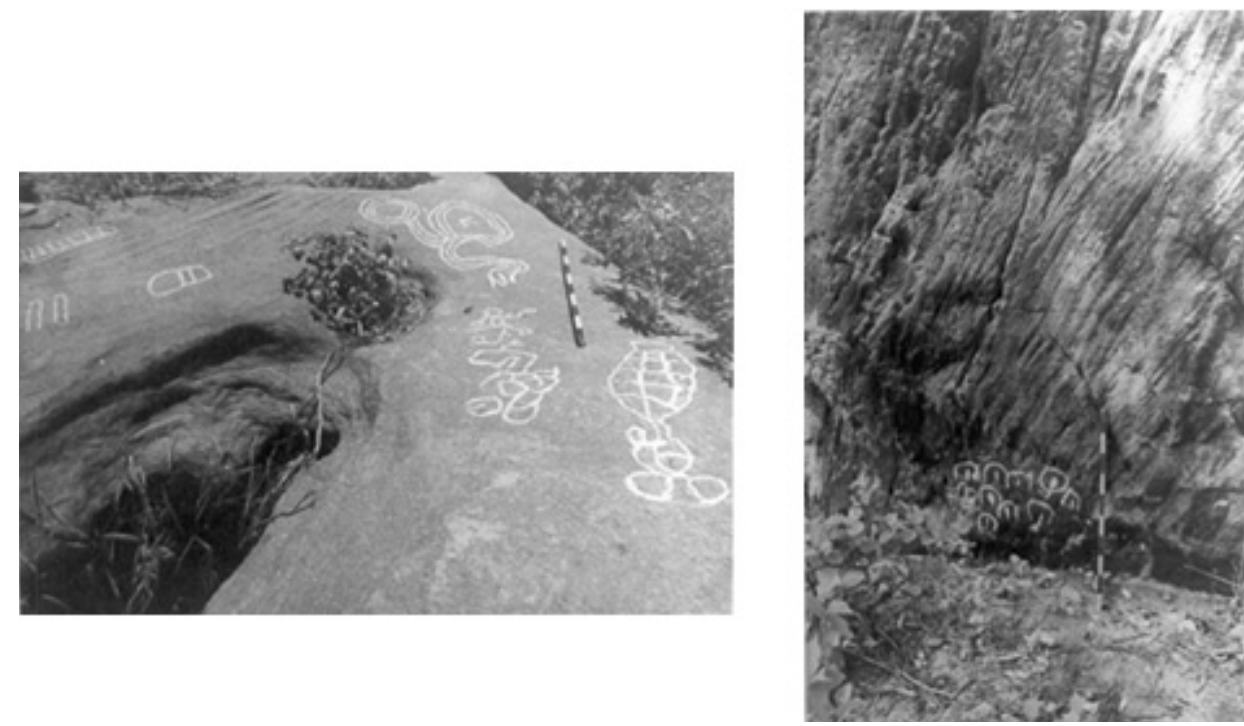

Figure 4 Photos of the archaeological sites Bebedouro das Pedras (left) and Pedra da Moeda (right), located in Rodelas (see Figure 2), showing the panels with petrogliphs that characterize these sites (Almeida and Galvão 1986).

\section{b) Paraíso}

This burial site is located at the top of the Dunes of Surubabel in the city of Rodelas. The site was excavated using $6 \times 6-\mathrm{m}$ squares and $2 \times 2$-m sub-squares. Da Silva (1987) and Etchevarne (1991) found lithic and ceramic artifacts, in addition to pipes, arrowheads, fireplace charcoal, and human bones and teeth.

\section{c) Aldeia do Vinho}

This open site is located in the river floodplain in the Varzea Grande region, in the city of Rodelas. In a superficial exploration, 734 lithic and 210 ceramic artifacts were found (da Silva 1987).

\section{d) Guga}

This open site is located in the river floodplain in the Picos de Penedo region, city of Rodelas. In excavations up to $1.15 \mathrm{~m}, 551$ lithic artifacts and 100 ceramic fragments were found (da Silva 1987; Etchevarne 1991).

\section{e) Tapera Velha - Casa Oeste}

This open site is located in tabular terrain in the region of Tapera Velha, city of Rodelas. In a superficial exploration, 1219 lithic artifacts and 1085 ceramic fragments were excavated (da Silva 1987; Etchevarne 1991). In some layers of this site, the old material found was mixed with fragments of porcelain, forks, brass stamps, and other relatively modern household utensils. An 18th century cop- 
per Brazilian colonial coin produced by the Bahia mint and pierced in the center, likely used as an ornament, was also found.

The large number of petrogliphs and lithic and ceramic artifacts found in the Itaparica Dam regionincluding chopping tools, a polished stone ax, stamps, pestles, and pottery-clearly indicate the settlement of earlier hunter-gatherer groups in this area. Among the materials collected in the studied sites, a significant amount of charcoal from fireplaces was selected and used for dating purposes, the results of which are discussed in the next section.

\section{EXPERIMENTAL PROCEDURE}

Dating was conducted by the ${ }^{14} \mathrm{C}$ dating facility at the Laboratory of Nuclear Geophysics of the Federal University of Bahia. The facility uses a conventional combustion line, where the samples are burned and the resulting $\mathrm{CO}_{2}$ is transported to a vacuum purification line. The gas is transported through the purification line by cooling the line sections with liquid nitrogen. The cleaned gas is then introduced in a decay counting system comprised of a gas ionization detector, an anticoincidence concentric guard circuit, and a lead and iron brick shield assembly (Taylor 1987).

The charcoal samples from several sites of the Itaparica Dam were classified according to appearance and amount. The samples for dating were chosen because of their relevance for the archaeological understanding of the region, cleanliness, texture, and mass. Sixteen samples were chosen for ${ }^{14} \mathrm{C}$ dating.

Chemical treatment of the samples consisted of acid and alkali washes and neutralizations. Initially, the samples were washed in 5\% sulfuric acid for $30 \mathrm{~min}$ to dissolve carbonates from the environment that could contaminate the sample. The samples were then washed with distilled water until the samples reached $\mathrm{pH}$ 7. Next, the samples were digested for $1 \mathrm{hr}$ in a solution of $20 \mathrm{~g} / \mathrm{L}$ of sodium hydroxide at $60-80^{\circ} \mathrm{C}$ to neutralize the humic and other acids generated by the decomposition of the organic matter that could contaminate the original carbon found in the samples. The samples were washed again with distilled water until the samples reached $\mathrm{pH}$ 7. Finally, the samples were dried in an oven at $80^{\circ} \mathrm{C}$ and stored until the introduction into the combustion line.

The amount of charcoal used in the experiments was $>4 \mathrm{~g}$. The samples were burned, and the resulting $\mathrm{CO}_{2}$ was purified to eliminate halogen, oxygen, water vapor, and radon from the original gas stream, because they would cause interference in the beta particles counting process. The $\mathrm{CO}_{2}$ of each sample was also used to measure the carbon isotopic ratio $\left({ }^{13} \mathrm{C} /{ }^{12} \mathrm{C}\right.$, i.e. $\left.\delta^{13} \mathrm{C}\right)$ using the mass spectrometer Nuclide 3-60-RMS, and this value was used to correct the sample age, taking into account the isotopic fractionating effects. In all dating measures reported in this study, the National Bureau of Standards (NBS) oxalic acid (HOx1) was used as a standard. The values of $\delta^{13} \mathrm{C}$ were found using Pee Dee Belemnite (PDB) as standard. Background radiation was also regularly measured. The routine precision obtained by the Laboratory of Nuclear Geophysics when dating charcoal is $\sim 5 \%$ (or $\pm 160 \mathrm{yr}$ for 3000 -yr-old samples). When tested by interlaboratory calibrations, the accuracy was in good agreement with the reported results.

The ${ }^{14} \mathrm{C}$ ages were calculated, taking into account the average value and standard deviation for the background radiation counting, the average value and standard deviation counting for the NBS oxalic acid standard ( $\mathrm{HOx} 1)$, the sample isotopic ratio $\left(\delta^{13} \mathrm{C}\right)$, and the sample counting distribution taken over a few days (Stuiver and Polach 1977; Stuiver 1980). 


\section{RESULTS AND DISCUSSION}

The ages given in Tables 1 and 2 are "conventional" ${ }^{14} \mathrm{C}$ ages corrected for $\delta^{13} \mathrm{C}$ (Taylor 1987). The ages for samples from the Itacoatiara I site (Bah.1527, Bah.1528, and Bah.1529 in Table 1) show the expected trend of older samples increasing in age with sediment depth. Also, the results for the Itacoatiara I site, together with the archaeological findings, indicate that several groups of hunter-gatherers have occupied the Itaparica Dam region in different periods. These distinct groups are the producers of the different kinds of lithic artifacts, including chopping tools, a polished stone ax, stamps and pestles, and the petrogliphs found in the sites of this region (see Figures 3 and 4). Note that for this site, the oldest age is $2290 \mathrm{BP}$, which is close to the values found for the intermediate levels of the well-studied site of Gruta do Padre (Calderón 1969; Almeida and Galvão 1986; da Silva 1987; Etchevarne 1991).

Table $1{ }^{14} \mathrm{C}$ dates for the site Itacotiara I.

\begin{tabular}{llll}
\hline $\begin{array}{l}\text { Lab code } \\
\text { Bah.- }\end{array}$ & Sample provenience & $\begin{array}{l}{ }^{14} \mathrm{C} \text { age } \pm 1 \sigma \\
(\mathrm{BP})\end{array}$ & $\begin{array}{l}\delta^{13} \mathrm{C} \\
(\%))^{\mathrm{a}}\end{array}$ \\
\hline 1525 & $\begin{array}{l}\text { Square: } 4 \mathrm{~A} \\
\text { Depth: } 10-20 \mathrm{~cm}\end{array}$ & $420 \pm 160$ & -24.14 \\
1527 & $\begin{array}{l}\text { Square: } 7 \mathrm{~A} \\
\text { Depth: } 10-20 \mathrm{~cm}\end{array}$ & Modern & -24.00 \\
1528 & $\begin{array}{l}\text { Square: 7A } \\
\text { Depth: } 20-30 \mathrm{~cm}\end{array}$ & $580 \pm 160$ & -24.08 \\
1529 & $\begin{array}{l}\text { Square: } 7 \mathrm{~A} \\
\text { Depth: } 50-70 \mathrm{~cm}\end{array}$ & $2290 \pm 170$ & -22.93 \\
1530 & $\begin{array}{l}\text { Square: } 3 \mathrm{~B} \\
\text { Depth: } 20-30 \mathrm{~cm}\end{array}$ & $1130 \pm 160$ & -24.53 \\
1531 & $\begin{array}{l}\text { Square: } 5 \mathrm{~B} \\
\text { Depth: } 20-30 \mathrm{~cm}\end{array}$ & $570 \pm 160$ & -24.43 \\
1533 & $\begin{array}{l}\text { Square: } 6 \mathrm{~B} \\
\text { Depth: } 30-40 \mathrm{~cm}\end{array}$ & $1590 \pm 170$ & -24.17 \\
1534 & $\begin{array}{l}\text { Square: } 5 \mathrm{~A} \\
\text { Depth: } 40-50 \mathrm{~cm}\end{array}$ & $1310 \pm 150$ & -23.76 \\
& & & \\
\hline
\end{tabular}

${ }^{a}$ With respect to PDB.

The results for the site Guga (Bah.1597, Bah.1598, and Bah.1599), located in river floodplains, show the expected trend of increasing age with sediment depth. In this case, however, the distinction between the ages is not strong, $\sim 3000 \mathrm{BP}$ in all cases.

The result for the site Tapera Velha - Casa Oeste (Bah.1600), located in tabular terrain, shows a relatively early age of $210 \mathrm{BP}$. This result can be explained by the superficial collection and matches very well with the relatively modern artifacts found in the studied level $(20 / 30 \mathrm{~cm})$ mentioned above, in the Itaparica Dam Sites section (da Silva 1987; Etchevarne 1991).

The results for the Paraíso site (Bah.1595 and Bah.1596), a burial site located at the top of dunes, give the oldest ages (3840 BP) among the sites of the Itaparica Dam region. However, a strong variation was found in the results of relatively close level depth, which seems to be caused by the natural mixing process that takes place in active dunes (Etchevarne 1991). 
Table $2{ }^{14} \mathrm{C}$ dates for the sites Aldeia do Vinho, Paraíso, Guga, and Tapera Velha-Casa Oeste.

\begin{tabular}{|c|c|c|c|c|}
\hline $\begin{array}{l}\text { Lab code } \\
\text { Bah.- }\end{array}$ & Site name & Sample provenience & $\begin{array}{l}{ }^{14} \mathrm{C} \text { age } \pm 1 \sigma \\
(\mathrm{BP})\end{array}$ & $\begin{array}{l}\delta^{13} \mathrm{C} \\
(\% o)^{\mathrm{a}}\end{array}$ \\
\hline 1594 & Aldeia do Vinho & $\begin{array}{l}\text { Square: } 1 \text { (Eroded scarps \#1) } \\
\text { Layer: Shells (3rd geologic } \\
\text { structure) }\end{array}$ & $2780 \pm 170$ & -23.50 \\
\hline 1595 & Paraíso & $\begin{array}{l}\text { Square: } 2 \mathrm{D} \\
\text { Sub-square: } 9 \\
\text { Depth: } 10-20 \mathrm{~cm}\end{array}$ & $810 \pm 150$ & -23.85 \\
\hline 1596 & Paraíso & $\begin{array}{l}\text { Square: } 2 \mathrm{E} \\
\text { Sub-square: } 7 \\
\text { Depth: } 10 \mathrm{~cm}\end{array}$ & $3840 \pm 180$ & -24.48 \\
\hline 1597 & Guga & $\begin{array}{l}\text { Transversal cut: } 3 \\
\text { Depth: } 30-40 \mathrm{~cm}\end{array}$ & $3140 \pm 170$ & -24.28 \\
\hline 1598 & Guga & $\begin{array}{l}\text { Transversal cut: } 4 \\
\text { Depth: } 62-78 \mathrm{~cm}\end{array}$ & $2900 \pm 170$ & -23.50 \\
\hline 1599 & Guga & $\begin{array}{l}\text { Transversal cut: } 3 \\
\text { Depth: } 92 \mathrm{~cm}\end{array}$ & $3250 \pm 180$ & -24.81 \\
\hline 1600 & Tapera Velha - Casa Oeste & $\begin{array}{l}\text { Square: } 1 \\
\text { Depth: } 20-30 \mathrm{~cm}\end{array}$ & $210 \pm 140$ & -23.51 \\
\hline
\end{tabular}

${ }^{a}$ With respect to PDB.

The ${ }^{14} \mathrm{C}$ ages for the fireplace charcoal found at the archaeological sites of the Itaparica Dam area, together with the findings of the rescue archaeological excavation that includes artifacts produced using different techniques, indicate the presence of hunter-gatherers in different settlement periods. For the site Itacoatiara I, for instance, the dates indicate an earlier settlement period at $\sim 2300 \mathrm{BP}$, an intermediate period of $\sim 1300 \mathrm{BP}$, and a more recent period of $\sim 500 \mathrm{BP}$.

\section{CONCLUSIONS}

This study provides ${ }^{14} \mathrm{C}$ ages for some archaeological sites found in the lower-middle section of the São Francisco River, specifically in the Bahia riverside of the Itaparica Dam area. The "conventional" ${ }^{14} \mathrm{C}$ ages for these sites, together with petrogliphs and lithic artifacts and pottery fragments indicate the presence of hunter-gatherers in this area from 3840 to $210 \mathrm{BP}$. These results suggest that the archaeological sites in the region are contemporary with intermediate levels of older sites found in the adjacent area of the São Francisco River, such as Lagoa Santa and Gruta do Padre, which, taking into account the archaeological findings for these layers, seem to indicate different settlement periods.

\section{ACKNOWLEDGMENTS}

This work was supported by the Conselho Nacional de Desenvolvimento Científico e Tecnológico (CNPq, Brazil). Antônio Expedito Gomes de Azevedo (Department of Nuclear Geophysics, Federal University of Bahia), Pedro Manoel Agostinho da Silva, Carlos Alberto Etchevarne, and other researchers from the Museum of Archaeology and Ethnology (Department of Anthropology, Federal University of Bahia) are gratefully acknowledged for helpful discussions and support. 


\section{REFERENCES}

Almeida LMR, Galvão V de FN. 1986. Report of the first stage of the Archaeological Excavation Rescue Project for Itaparica of São Francisco. Agreement between the Association for Archaeology and Prehistory of Bahia and the São Francisco Hydroelectric Company (CHESF). 72 p. In Portuguese.

Calderón V. 1967. Preliminary news about the archaeological sequence of the middle São Francisco River and the Chapada Diamantina, Bahia State. In: Programa Nacional de Pesquisas Arqueológicas. Publicações Avulsas. Belém, Brazil: Museu Paraense Emílio Goeldi. p 107-19. In Portuguese.

Calderón V. 1969. Preliminary notes about the archaeology of the center and southwestern Bahia State. In: Programa Nacional de Pesquisas Arqueológicas. Publicacões Avulsas. Belém, Brazil: Museu Paraense Emílio Goeldi. p 135-46. In Portuguese.

Calderón V. 1972. The lithic traditions of a region of the low-middle São Francisco River, Bahia. Universitas 12/13:49-62. Federal University of Bahia, Brazil. In Portuguese.

Calderón V. 1983. Studies of archaeology and ethnology. Federal University of Bahia, Brazil. In Portuguese.

da Silva PMA. 1987. Report of the second stage of the archaeological excavation rescue project for Itaparica of São Francisco. Agreement between the São Francisco Hydroelectric Company (CHESF) and the Federal University of Bahia (UFBA). 74 p. In Portuguese.

de Souza HCA. 1945. The Itaparica Falls in the São Francisco River. Brasilia: Departamento Nacional da Produção Mineral. In Portuguese.

Dillehay TD, Calderon GA, Politis G, Beltrão MDDC. 1992. Earliest hunter-gatherers of South America. Journal of World Prehistory 6(2):145-204.

Etchevarne CA. 1991. Site in Dunes: a contribution to the archaeology of the sub-middle São Francisco River [MSc dissertation]. São Paulo: University of São Paulo. 228 p. In Portuguese.

Martin G, Rocha J. 1986. The lithic industry in ltaparica, middle São Francisco Valley (Pernambuco, Brazil), CLIO [journal]: Recife 8, Archaeological series 3. p 99-135.

Martin G, Rocha J. 1989. The site "Letreiro do Sobrado" Petrolândia PE. DÉDALO [journal]. São Paulo: Pub. Avulsa. p 473-86. In Portuguese.

Martin G. 1999. The Brazilian Northeast Prehistory. 3rd edition. Recife: Federal University of Pernambuco.
440 p. In Portuguese.

Nazario FAS, Shayani S, Lucas NM. 1979. The stability study of unstable wedges caused by large excavations at Itaparica Dam. In: Proceedings of the 4th Congress International Society for Rock Mechanics. Rotterdam: Balkema. p 699-702.

Neves WA, Gonzalez-Jose R, Hubbe M, Kipnis R, Araujo AGM, Blasi O. 2004. Early Holocene human skeletal remains from Cerca Grande, Lagoa Santa, central Brazil, and the origins of the first Americans. World Archaeology 36(4):479-501.

Peyre E. 1993. New discovery of a prehistoric human in America - a 9700-year-old Brazilian woman. Comptes Rendus de l'Academie des Sciences, Serie II 316(6):839-42. In French.

Portella T. 1992. The Hydroelectric Plant at Itaparica: A Struggle with Power. Petrolândia, Brazil: Centro de Defesa dos Direitos Humanos do Submedio São Francisco.

Prous A. 1986. Archaeology in Brazil: 300 centuries of human occupation. L'Antropologie 90(2):257-306. In French.

Prous A. 1992. Brazilian Archaeology. Brasilia: University of Brasilia Press. 605 p. In Portuguese.

Prous A, Fogaça E. 1999. Archaeology of the Pleistocene-Holocene boundary in Brazil. Quaternary International 53/54:21-41.

Rowe MW, Steelman KL. 2003. Comment on "Some Evidence of a Date of First Humans to Arrive in Brazil." Journal of Archaeological Science 30:1349-51.

Santos GM, Bird MI, Parenti F, Fifield LK, Guidon N, Hausladen PA. 2003. A revised chronology of the lowest occupation layer of Pedra Furada Rock Shelter, Piauí, Brazil: the Pleistocene peopling of the Americas. Quaternary Science Reviews 22:2303-10.

Schmitz PI. 1987. Prehistoric hunter-gatherers of Brazil. Journal of World Prehistory I:53-126.

Stuiver M. 1980. Workshop on ${ }^{14} \mathrm{C}$ data reporting. Radiocarbon 22(3):964-6.

Stuiver M, Polach HA. 1977. Discussion: reporting of ${ }^{14} \mathrm{C}$ data. Radiocarbon 19(3):355-63.

Taylor RE. 1987. Radiocarbon Dating: An Archaeological Perspective. San Diego: Academic Press, Inc.

Watanabe S, Ayta WEF, Hamaguchi N, Guidon N, La Salvia ES, Maranca S, Baffa Filho O. 2003. Some evidence of a date of first humans to arrive in Brazil. Journal of Archaeological Science 30:351-4. 